\title{
Land Cover Trends Dataset, 1973-2000
}

1973 Landsat MSS

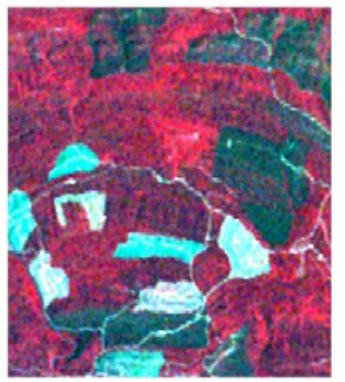

1973 LULC

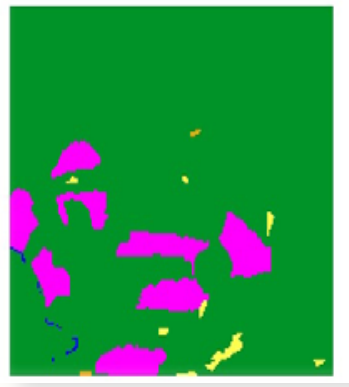

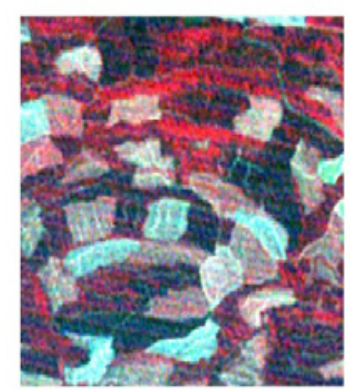

1980 LULC

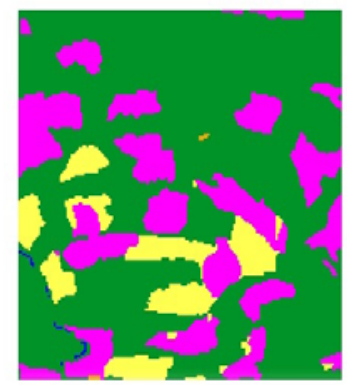

1992 Landsat TM 2000 Landsat ETM+

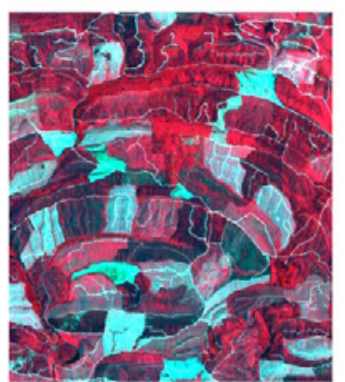

1986 LULC

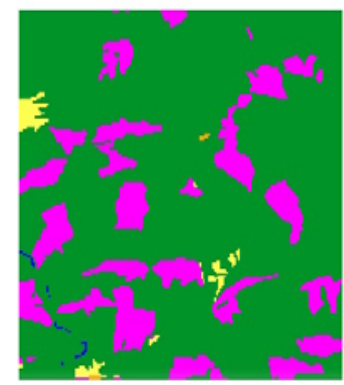

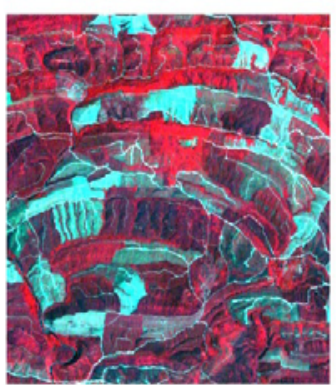

1992 LULC

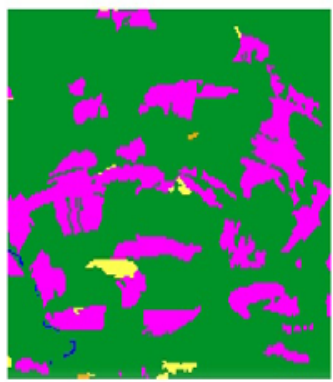

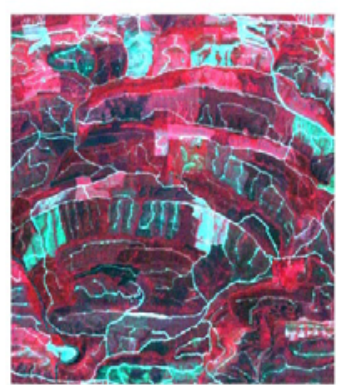

2000 LULC

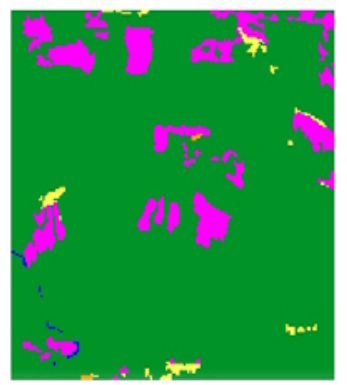

Data Series 844 
COVER

An example of the five dates of Landsat imagery and corresponding land-use/land-cover data available for each sample block. The example sample block is located in the Ouachita Mountains Ecoregion (samp36_0180), and shows forest cutting from 1973 to 2000 (green, forest/woodland; yellow, grassland/shrubland; magenta, mechanical disturbance; blue, water). 


\section{Land Cover Trends Dataset, 1973-2000}

By Christopher E. Soulard, William Acevedo, Roger F. Auch, Terry L. Sohl, Mark A. Drummond, Benjamin M. Sleeter, Daniel G. Sorenson, Steve Kambly, Tamara S. Wilson, Janis L. Taylor, Kristi L. Sayler, Michael P. Stier, Christopher A. Barnes, Steve C. Methven, Thomas R. Loveland, Rachel Headley, and Mark S. Brooks

Data Series 844 


\title{
U.S. Department of the Interior SALLY JEWELL, Secretary
}

\section{U.S. Geological Survey Suzette M. Kimball, Acting Director}

\author{
U.S. Geological Survey, Reston, Virginia: 2014
}

For more information on the USGS - the Federal source for science about the Earth, its natural and living resources, natural hazards, and the environment-visit http://www.usgs.gov or call 1-888-ASK-USGS

For an overview of USGS information products, including maps, imagery, and publications, visit http://www.usgs.gov/pubprod

To order this and other USGS information products, visit http://store.usgs.gov

Any use of trade, firm, or product names is for descriptive purposes only and does not imply endorsement by the U.S. Government.

Although this information product, for the most part, is in the public domain, it also may contain copyrighted materials as noted in the text. Permission to reproduce copyrighted items must be secured from the copyright owner.

Suggested citation:

Soulard, C.E., Acevedo, W., Auch, R.F., Sohl, T.L., Drummond, M.A., Sleeter, B.M., Sorenson, D.G., Kambly, S., Wilson, T.S., Taylor, J.L., Sayler, K.L., Stier, M.P., Barnes, C.A., Methven, S.C., Loveland, T.R., Headley, R., and Brooks, M.S., 2014, Land cover trends dataset, 1973-2000: U.S. Geological Survey Data Series 844, 10 p., http://dx.doi.org/10.3133/ds844.

ISSN 2331-1258 (online) 


\section{Acknowledgments}

Development of this dataset was supported by the U.S. Geological Survey (USGS) Geographic Analysis and Monitoring Program, USGS Climate and Land Use Change Research and Development Program, U.S. Environmental Protection Agency, and National Aeronautics

and Space Administration. The creation of the Land Cover Trends Dataset could not have been completed without the significant contributions of the following team members: Randy Alexander, J.D. Cox, Keith Landgraf, Amy Mathie, Robert Glover, Barry Middleton, Alisa Gallant, Bev Friesen, Leila Gass, Michelle Knuppe, Brad Lodge, John Vogel, Pam Waisanen, Jana Ruhlman, Jerry Griffith, Christian Raumann, Steve Blauer, Rachel Sleeter, Glenn Griffith, Christy Ryan, Greg Zylstra, Leslie Lansberry, Carl Rich, Leslie Milheim, Brian Fiehler, Tom Moreland, Jim Vaughn, Susan Maxwell, Danielle Aiello, Jeanne Jones, Lori Baer, and Paul Martin. 


\section{Contents}

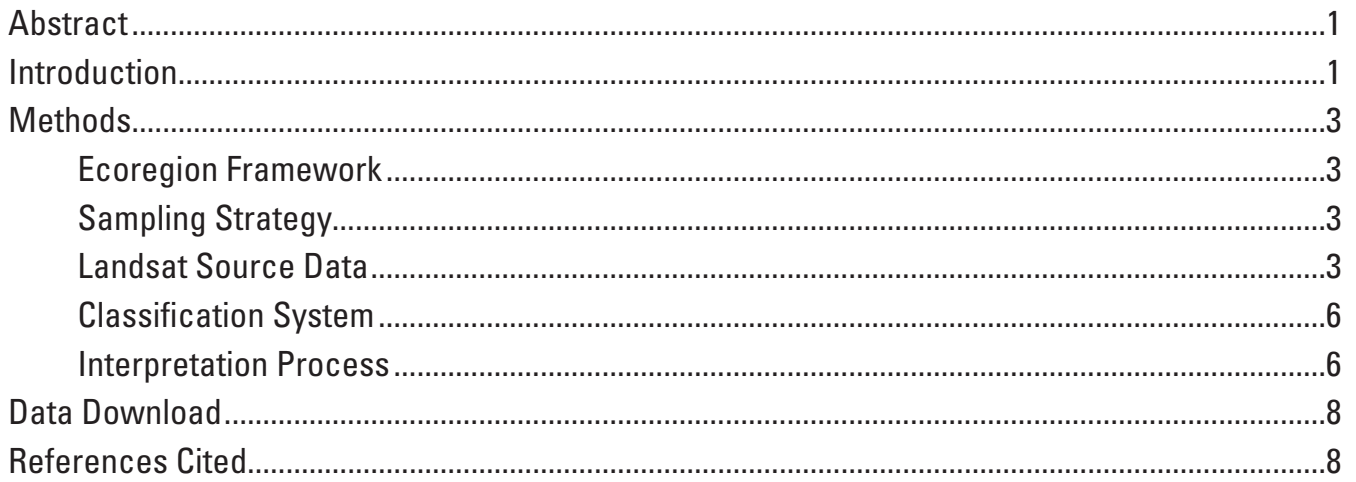

\section{Figures}

1. Map showing locations of 2,688 sample blocks within 84 EPA Level III ecoregions across the conterminous United States that comprise the Land Cover Trends Dataset..............2

2. Flow diagram depicting block interpretation procedure used to develop Land Cover Trends Dataset

3. Example of five dates of LULC data available for each sample block... .9

\section{Tables}

1. Ecoregion number, name, number of randomly selected sample blocks, total blocks in each ecoregion, and percentage of ecoregion mapped ................................................4

2. Landsat data used to develop Land Cover Trends Dataset..........................................................6

3. LULC classification system used to develop data for the Land Cover Trends Dataset ..............7

4. Data sources and dates of ancillary data acquired to aid researchers in manually delineating land use and land cover from Landsat imagery 


\section{Conversion Factors}

SI to Inch/Pound

\begin{tabular}{|c|c|c|}
\hline Multiply & By & To obtain \\
\hline \multicolumn{3}{|c|}{ Length } \\
\hline meter $(\mathrm{m})$ & 3.281 & foot (ft) \\
\hline kilometer (km) & 0.6214 & mile (mi) \\
\hline
\end{tabular}

Horizontal coordinate information is referenced to the North American Datum of 1983 (NAD 83).

\section{Acronyms and Abbreviations}

$\begin{array}{ll}\text { EPA } & \text { U.S. Environmental Protection Agency } \\ \text { ETM+ } & \text { Enhanced Thematic Mapper Plus } \\ \text { LULC } & \text { land-use/land-cover } \\ \text { MRLC } & \text { Multi-Resolution Land Characteristics Consortium } \\ \text { MSS } & \text { Multispectral Scanner } \\ \text { NALC } & \text { North American Landscape Characterization } \\ \text { NLCD } & \text { National Land Cover Dataset } \\ \text { TM } & \text { Thematic Mapper } \\ \text { USGS } & \text { U.S. Geological Survey }\end{array}$





\title{
Land Cover Trends Dataset, 1973-2000
}

\author{
By Christopher E. Soulard, William Acevedo, Roger F. Auch, Terry L. Sohl, Mark A. Drummond, Benjamin M. \\ Sleeter, Daniel G. Sorenson, Steve Kambly, Tamara S. Wilson, Janis L. Taylor, Kristi L. Sayler, Michael P. Stier, \\ Christopher A. Barnes, Steve C. Methven, Thomas R. Loveland, Rachel Headley, and Mark S. Brooks
}

\section{Abstract}

The U.S. Geological Survey Land Cover Trends Project is releasing a 1973-2000 time-series land-use/land-cover dataset for the conterminous United States. The dataset contains 5 dates of land-use/land-cover data for 2,688 sample blocks randomly selected within 84 ecological regions. The nominal dates of the land-use/land-cover maps are 1973, 1980, 1986, 1992, and 2000. The land-use/land-cover maps were classified manually from Landsat Multispectral Scanner, Thematic Mapper, and Enhanced Thematic Mapper Plus imagery using a modified Anderson Level I classification scheme. The resulting land-use/land-cover data has a 60-meter resolution and the projection is set to Albers Equal-Area Conic, North American Datum of 1983. The files are labeled using a standard file naming convention that contains the number of the ecoregion, sample block, and Landsat year. The downloadable files are organized by ecoregion, and are available in the ERDAS IMAGINE $^{\mathrm{TM}}$ (.img) raster file format.

\section{Introduction}

Researchers with the U.S. Geological Survey (USGS) Land Cover Trends Project created a dataset for the conterminous United States designed to characterize the historical state of the nation's land surface from 1973 to 2000 . The dataset allows one to analyze patterns, rates, and trends in land-use/ land-cover (LULC) change and to assess the causes and potential consequences of LULC change across the country (Loveland and others, 2002). The dataset documents the geographic variability and characteristics of national landscape change from 1973 to 2000, and provides a scientific foundation for assessing the environmental consequences of LULC change. More than 60 scientific papers have been published and the results have served as the basis for collaborative studies of the environmental consequences of change with scientists from many organizations including the U.S. Geological Survey, U.S. Environmental Protection Agency, National Aeronautics and Space Administration, National Oceanic and Atmospheric Association, National Science Foundation, U.S. Fish and Wildlife Service, and academia.
Many Federal agencies use statistical surveys or remote sensing to track specific LULC information pertaining to research goals or land-management needs. For instance, the Forest Inventory and Analysis Program of the U.S. Forest Service provide the information needed to assess status and trends in America's forests (Gillespie, 1999). The U.S. Department of Agriculture Census of Agriculture is the leading source of facts and figures about American agriculture (U.S. Department of Agriculture, 2009a). The U.S. Department of Agriculture National Resources Inventory is a statistical survey of LULC and natural resource conditions and trends on non-Federal lands (U.S. Department of Agriculture, 2009b). The USGS's National Land Cover Database only recently became a source of 30-meter resolution, Landsat-based, spatial land-cover data for the Nation, containing layers for thematic LULC, percent developed imperviousness, and percent tree canopy density (Fry and others, 2011). Each effort contributes to our understanding of the land use and land cover, but none offer a complete, comprehensive assessment of LULC change for 1973-2000 based on methods that are spatially and temporally consistent across the conterminous U.S.

The Land Cover Trends dataset for 1973-2000 was created using a statistical sampling approach because it was a cost efficient method for characterizing LULC change across large areas such as the United States (Stehman and others, 2003). Ecological regions were used as a geographic framework for selecting sample blocks across the conterminous United States. A total of 2,688 sample blocks were randomly selected from 84 Level III ecoregions (Omernik, 1987) (fig. 1). Researchers manually interpreted Landsat Multispectral Scanner (MSS), Thematic Mapper (TM), and Enhanced Thematic Mapper Plus (ETM+) imagery for five dates (1973, 1980, 1986, 1992, and 2000), and then used the LULC data to derive change statistics for each time period (1973-1980, 1980-1986, 1986-1992, and 1992-2000) and for the entire study period (1973-2000), ultimately serving as the basis for ecoregion-based LULC change estimates used as the primary land-change metrics in reporting.

The LULC change estimates are used to determine (1) the predominant types of LULC conversions occurring within each ecoregion; (2) the estimated rates of change for these conversions; and (3) whether the types, rates, and patterns of change are constant or variable across space and time. The 


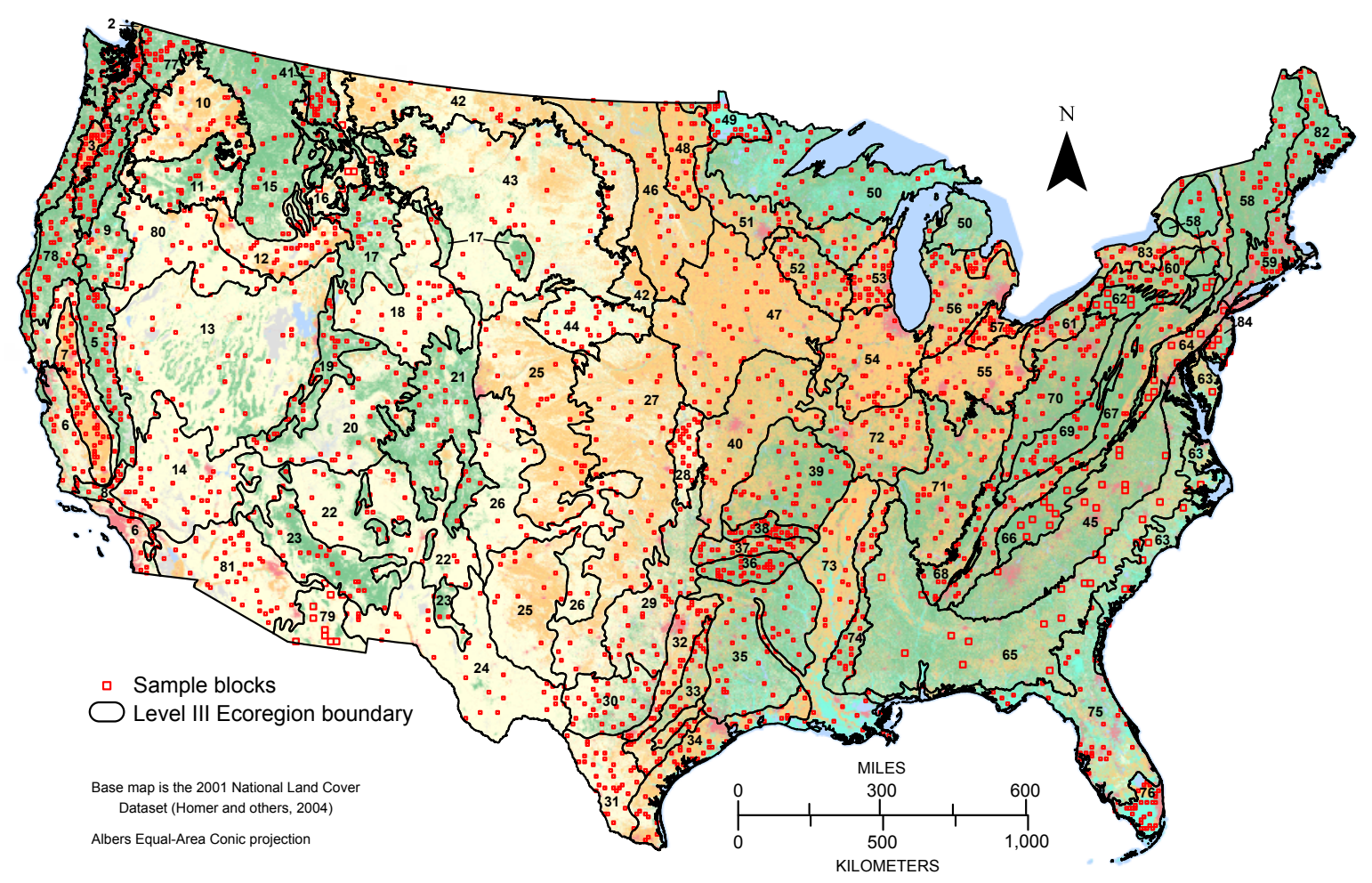

\begin{tabular}{|c|c|c|c|c|c|c|c|}
\hline $\begin{array}{c}\text { Ecoregion } \\
\text { number }\end{array}$ & Ecoregion name & $\begin{array}{c}\text { Ecoregion } \\
\text { number }\end{array}$ & Ecoregion name & $\begin{array}{l}\text { Ecoregion } \\
\text { number }\end{array}$ & Ecoregion name & $\begin{array}{c}\text { Ecoregion } \\
\text { number }\end{array}$ & Ecoregion name \\
\hline 1 & Coast Range & 22 & Arizona/New Mexico Plateau & 43 & Northwestern Great Plains & 64 & Northern Piedmont ${ }^{1}$ \\
\hline 2 & Puget Lowland & 23 & $\begin{array}{l}\text { Arizona/New Mexico } \\
\text { Mountains }\end{array}$ & 44 & Nebraska Sand Hills & 65 & Southeastern Plains ${ }^{1}$ \\
\hline 3 & Willamette Valley & 24 & Chihuahuan Deserts & 45 & Piedmont $^{1}$ & 66 & 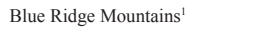 \\
\hline 4 & Cascades & 25 & Western High Plains & 46 & Northern Glaciated Plains & 67 & Ridge and Valley \\
\hline 5 & Sierra Nevada & 26 & Southwestern Tablelands & 47 & Western Corn Belt Plains & 68 & Southwestern Appalachians \\
\hline 6 & $\begin{array}{l}\text { California Chaparral and Oak } \\
\text { Woodlands }\end{array}$ & 27 & Central Great Plains & 48 & Lake Agassiz Plain & 69 & Central Appalachians \\
\hline 7 & Central California Valley & 28 & Flint Hills & 49 & Northern Minnesota Wetlands & 70 & Western Allegheny Plateau \\
\hline 8 & Southern California Mountains & 29 & Central Oklahoma/Texas Plains & 50 & Northern Lakes and Forests & 71 & Interior Plateau \\
\hline 9 & $\begin{array}{l}\text { Eastern Cascades Slopes and } \\
\text { Foothills }\end{array}$ & 30 & Edwards Plateau & 51 & North Central Hardwood Forests & 72 & Interior River Lowland \\
\hline 10 & Columbia Plateau & 31 & Southern Texas Plains & 52 & Driftless Area & 73 & Mississippi Alluvial Plain \\
\hline 11 & Blue Mountains & 32 & Texas Blackland Prairies & 53 & Southeastern Wisconsin Till Plains & 74 & Mississippi Valley Loess Plains \\
\hline 12 & Snake River Basin & 33 & East Central Texas Plains & 54 & Central Corn Belt Plains & 75 & Southern Coastal Plain \\
\hline 13 & Central Basin and Range & 34 & Western Gulf Coastal Plain & 55 & Eastern Corn Belt Plains & 76 & Southern Florida Coastal Plain \\
\hline 14 & Mojave Basin and Range & 35 & South Central Plains & 56 & $\begin{array}{l}\text { Southern Michigan/Northern } \\
\text { Indiana Drift }\end{array}$ & 77 & North Cascades \\
\hline 15 & Northern Rockies & 36 & Ouachita Mountains & 57 & Huron/Erie Lake Plain & 78 & Klamath Mountains \\
\hline 16 & $\begin{array}{l}\text { Montana Valley and Foothill } \\
\text { Prairies }^{1}\end{array}$ & 37 & Arkansas Valley & 58 & Northeastern Highlands & 79 & Madrean Archipelago ${ }^{1}$ \\
\hline 17 & Middle Rockies & 38 & Boston Mountains & 59 & Northeastern Coastal Zone & 80 & Northern Basin and Range \\
\hline 18 & Wyoming Basin & 39 & Ozark Highlands & 60 & $\begin{array}{l}\text { Northern Appalachian Plateau and } \\
\text { Uplands }\end{array}$ & 81 & Sonoran Basin and Range \\
\hline 19 & Wasatch and Uinta Mountains & 40 & Central Irregular Plains & 61 & Erie Drift Plains & 82 & Laurentian Plains and Hills \\
\hline 20 & Colorado Plateaus & 41 & Canadian Rockies & 62 & North Central Appalachians ${ }^{1}$ & 83 & $\begin{array}{l}\text { Eastern Great Lakes and Hudson } \\
\text { Lowlands }\end{array}$ \\
\hline 21 & Southern Rockies & 42 & Northwestern Glaciated Plains & 63 & Middle Atlantic Coastal Plain ${ }^{1}$ & 84 & Atlantic Coastal Pine Barrens ${ }^{1}$ \\
\hline
\end{tabular}

Figure 1. Map showing locations of 2,688 sample blocks within 84 EPA Level III ecoregions across the conterminous United States that comprise the Land Cover Trends Dataset. 
analysis of change, which was described in several ecoregion publications and summarized in a national synthesis (Sleeter and others, 2013), also involved looking for spatial correlations between conversion types and selected environmental factors, such as terrain characteristics, proximity to urban development, economic conditions, and so on, in order to improve our understanding of potential drivers of change (Raumann and Soulard, 2007; Napton and others, 2010; Soulard and Wilson, 2013).

\section{Methods}

The Land Cover Trends Project was first proposed by Loveland and others (1999), and the project methodology was later published by Loveland and others (2002). Additional details on sampling design were provided by Stehman and others (2003) and Sleeter and others (2013). A detailed description of each facet of the Land Cover Trends methodology is provided here, including the ecoregion framework, sampling strategy, Landsat source data, classification system, and interpretation process.

\section{Ecoregion Framework}

A central premise of the project strategy was that EPA Level III ecoregions can provide an ideal geographic framework for characterizing regional LULC change. The ecoregion boundaries used were originally defined by Omernik (1987) and then revised by the U.S. Environmental Protection Agency (1999). The spatial boundaries were developed by synthesizing information on climate, geology, physiography, soils, vegetation, hydrology, and human factors, such that the ecoregions reflect patterns of LULC potential that correlate with patterns visible in remotely sensed data. This set of factors makes ecoregions suitable to chronicle regional stories of change, highlighting how LULC patterns, disturbance types and frequencies, environmental issues of concern, and management practices and consequences are similar regionally yet differ across the country. The Land Cover Trends project also uses this ecoregion framework because ecoregions (1) provide a means to localize estimates of the rates and driving forces of change; (2) play a significant role in determining the range of current LULC types, and the LULC trajectories that may occur in the future; and (3) provide a framework that can be extended globally.

\section{Sampling Strategy}

LULC composition and change was determined using a probability sample of 2,688 blocks randomly selected within 84 EPA Level III ecoregions (fig. 1; table 1). By adjusting the number of blocks selected for an ecoregion to the expected amount of LULC change, the total blocks in each ecoregion could be used to create LULC change estimates categorically "representative" of the ecoregion with high statistical confidence (Kish, 1987). Sample block dimensions were established based on the historical size and distribution of LULC change patterns over time. The initial design used a $20-\mathrm{km}^{2}$ sample size. Nine ecoregions were analyzed using 9-11 randomly selected $20 \times 20-\mathrm{km}$ sample blocks per ecoregion. The remaining 75 ecoregions were analyzed using $25-48$ randomly selected $10 \times 10-\mathrm{km}$ sample blocks per ecoregion because a greater number of smaller size sample blocks would provide improved estimates of LULC change in area and type over improved characterization of LULC change patterns.

The number of sample blocks selected for each ecoregion was based on expected LULC change characteristics and the project goal to measure change within \pm 1 -percent margin of error at an 85-percent confidence level. Sample block selection involved overlaying a grid of $10 \times 10-\mathrm{km}$ (or $20 \times 20-\mathrm{km}$ ) blocks over a map of the conterminous United States and assigning blocks to a specific ecoregion following a centroid spatial allocation rule. The sample blocks within each ecoregion then were assigned a unique numerical value from 1 to $\mathrm{N}$. A random number generator was used to select actual sample blocks one at a time until the total number of sample blocks was attained for each ecoregion.

\section{Landsat Source Data}

For each sample block, five dates of Landsat imagery were used to interpret and map LULC. The Landsat imagery provided a consistent, synoptic, multispectral view of the land surface from which information on LULC could be interpreted for 1973-2000.

Landsat MSS, TM, and ETM+ imagery was acquired from the North American Landscape Characterization (NALC) Project (Lunetta and others, 1998), the MultiResolution Land Characteristics Consortium (MRLC) Landsat Scene Library (Multi-Resolution Land Consortium, 2011), and the National Satellite Land Remote Sensing Data Archive (table 2). Landsat imagery acquired from NALC and MRLC had been used in other land characterization efforts and had the added benefits of low cost (prior to the Landsat archive becoming free to download) and robust pre-processing. The Landsat scenes acquired from NALC and MRLC were previously georeferenced to root-mean-square errors of 1 pixel or less. Additionally, most of the Landsat MSS data from NALC also had been corrected for terrain.

The Landsat scenes selected for the national Land Cover Trends mapping effort were spaced at semi-regular, 6-8-year intervals (1973, 1980, 1986, 1992, and 2000). These dates represent the core year, or center point, that each image represents. Image dates rarely deviated from \pm 1 year of these core dates, although there were some exceptions. Whenever possible, cloud free Landsat block images from approximately the same time in the calendar year were used. 
Table 1. Ecoregion number, name, number of randomly selected sample blocks, total blocks in each ecoregion (population), and percentage of ecoregion mapped.

[Sample blocks for each Level III ecoregion were randomly selected based on the ecoregion size and how much change was expected over the study period.]

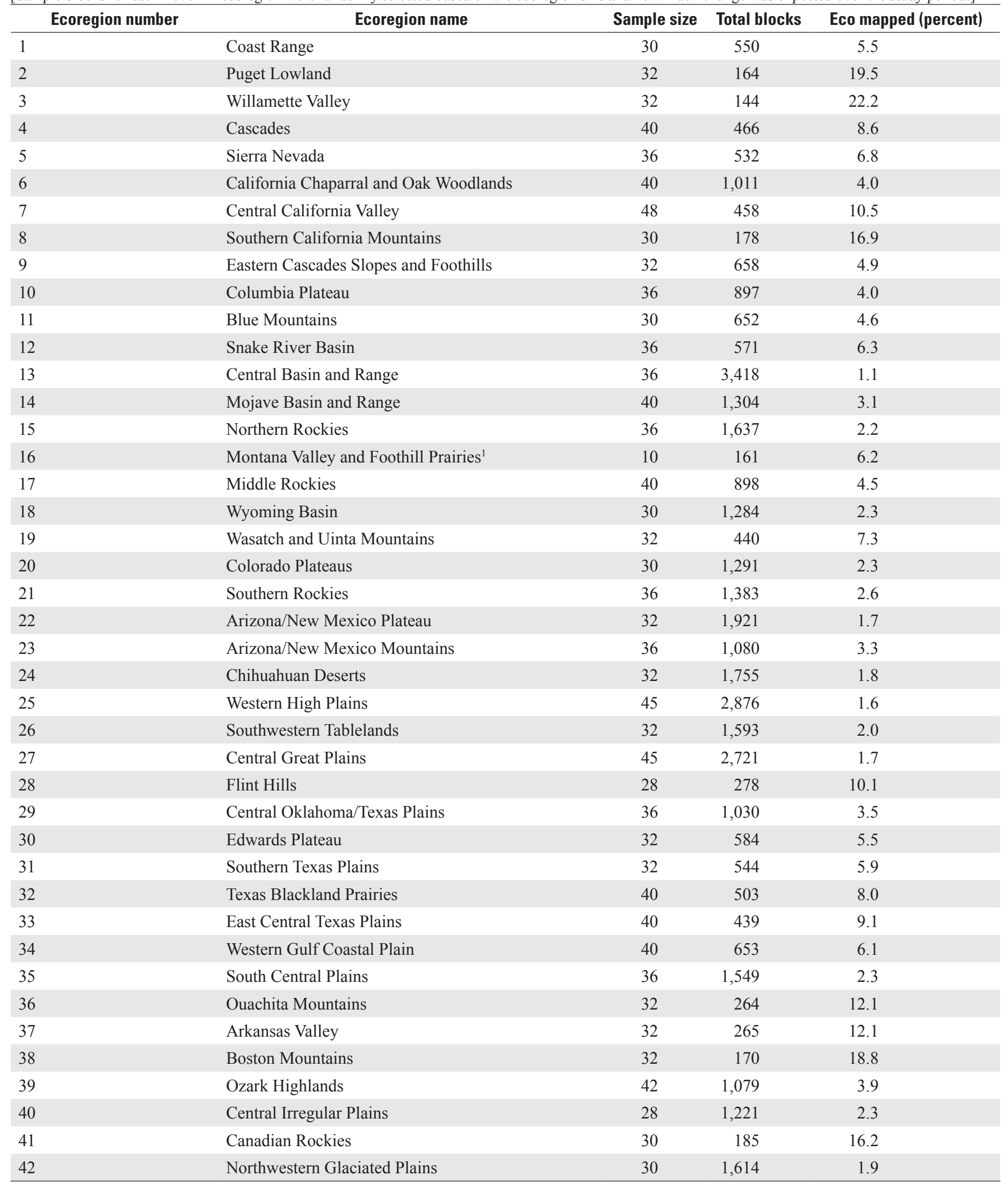

${ }^{1}$ Indicates ecoregion that had $20 \times 20$-kilometer sample blocks instead of $10 \times 10$-kilometer sample blocks. 
Table 1. Ecoregion number, name, number of randomly selected sample blocks, total blocks in each ecoregion (population), and percentage of ecoregion mapped.-Continued

[Sample blocks for each Level III ecoregion were randomly selected based on the ecoregion size and how much change was expected over the study period.]

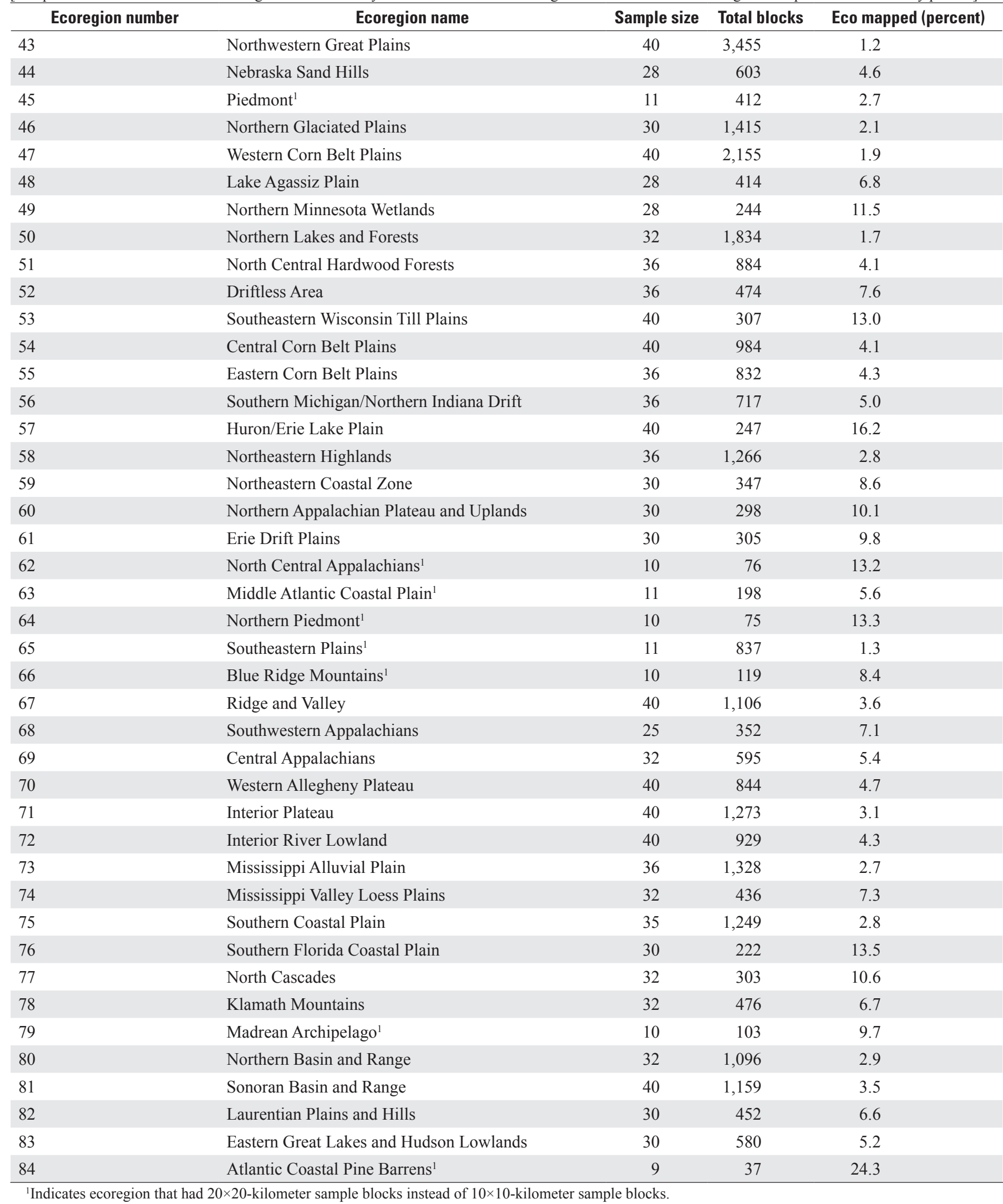


Table 2. Landsat data used to develop Land Cover Trends Dataset.

[Landsat sensor: ETM+, Enhanced Thematic Mapper Plus; MSS, Multispectral Scanner; TM, Thematic Mapper. Data source: Land Cover Trends Project mostly used Landsat imagery acquired by the North American Landscape Characterization (NALC) Project (Lunetta and others, 1998) and the Multi-Resolution Land Characteristics Consortium (MRLC) Landsat Scene Library (Multi-Resolution Land Consortium, 2011). Imagery for around 1980 were acquired from the National Satellite Land Remote Sensing Data Archive (NSLRSDA). Many of these data were available at no charge, and included additional pre-processing measures and steps to maintain registration consistency.]

\begin{tabular}{|c|c|c|c|}
\hline Nominal date & Landsat sensor & Resolution (meters) & Data source \\
\hline 1973 & MSS & 60 & NALC \\
\hline 1980 & MSS & 60 & NSLRSDA \\
\hline 1992 & TM, MSS & 30,60 & MRLC, NALC \\
\hline 2000 & ETM+ & 30 & MRLC \\
\hline
\end{tabular}

\section{Classification System}

The classification system for the Land Cover Trends Dataset consisted of 11 general LULC classes and is a modified version of the Anderson Level I classification system (Anderson and others, 1976). The classification system for the Land Cover Trends Dataset includes two transitional disturbance classes: (1) mechanically disturbed denotes humaninduced disturbances (for example, forest clear-cutting), and (2) nonmechanically disturbed denotes natural disturbances (for example, fire or insect infestation events). The decision to use general, Level I classes was primarily made to achieve high interpretation accuracy and consistency using moderate resolution imagery (table 3 ).

Because Landsat MSS, TM, and ETM+ imagery has limitations on what LULC classes can be correctly identified and/or what land changes can be discerned between images, LULC maps were classified at the lower spatial resolution of the Landsat MSS imagery. A minimum mapping unit of $60 \times 60$ meters was used for the study. This meant that features with ground footprints less than 60 meters wide, such as narrow roads or low-density development, were not mapped because their width was less than the minimum mapping unit.

\section{Interpretation Process}

LULC delineations for each sample block began with the creation of a baseline reference LULC dataset. The 1992 date was usually the starting point due to the availability of the 30-meter resolution 1992 National Land Cover Dataset (NLCD) (Vogelmann, 2001). The detailed Anderson Level II NLCD classes were aggregated to match the descriptions of the more general land-cover classification system used by the Land Cover Trends Project. The NLCD data then were digitally edited by the researcher using ERDAS IMAGINE ${ }^{\mathrm{TM}}$ software, using on-screen interpretation methods while viewing the 1992 Landsat TM data along with aerial photographs (National Aerial Photography Program and National High Altitude Program) and other ancillary aids (Google Earth ${ }^{\mathrm{TM}}$, topographic maps, National Wetland Inventory datasets, and so on), which assisted and improved interpretations (table 4). This digital editing (that is, cleanup) procedure was done because NLCD data were created using automated spectral image processing procedures and were not meant for use in local-scale assessments. Additionally, the Land Cover Trends Project aimed to improve on the NLCD data by explicitly mapping land-disturbance events. The use of manual, pixelby-pixel classification distinguishes this process from many other change-detection processes where automated spectral image products are used directly in the change-detection process without human involvement to improve the quality of the classification.

LULC for 1986 and 2000 was backward- or forwardclassified using the interpreted 1992 LULC data as a template. For example, creation of the 2000 LULC image began by making an exact copy of the 1992 LULC image. This copy served as a baseline for the 2000 LULC image, with identified changes from 1992 to 2000 manually edited into the copied image. This baseline 2000 LULC image, the 1992 Landsat imagery, and the 2000 Landsat imagery were displayed on the computer screen using linked windows, allowing the analyst to view the entire area covered by the sample block, examining the 1992 and 2000 Landsat imagery and any relevant aerial photography and ancillary data (table 4) for valid LULC changes between the two dates. Any identified LULC changes were manually digitized on-screen, and the LULC classified in the 2000 LULC raster image.

Upon completion of the 2000 LULC image, the same procedures were used to create the 1986 LULC map by backclassifying areas that changed from the 1992 map based on differences in the 1986 Landsat imagery (fig. 2). The procedure then was repeated using the 1986 LULC image as the basis to map areas that changed in 1980, and the resulting 1980 image used to map areas that changed in 1973. This manual process eliminates errors that may arise between independently created LULC images for two dates prior to a spatial change analysis. Classification errors are greatly reduced because only manually identified, delineated, and coded LULC changes are delineated during this procedure.

A traditional accuracy assessment was not done for the interpreted sample blocks. However, quality-assurance and quality-control measures consisted of a formal block review 
Table 3. LULC classification system used to develop data for the Land Cover Trends Dataset.

[The classification system for the Land Cover Trends Dataset consisted of 11 general LULC classes and is a modified version of the Anderson Level I classification system (Anderson and others, 1976).]

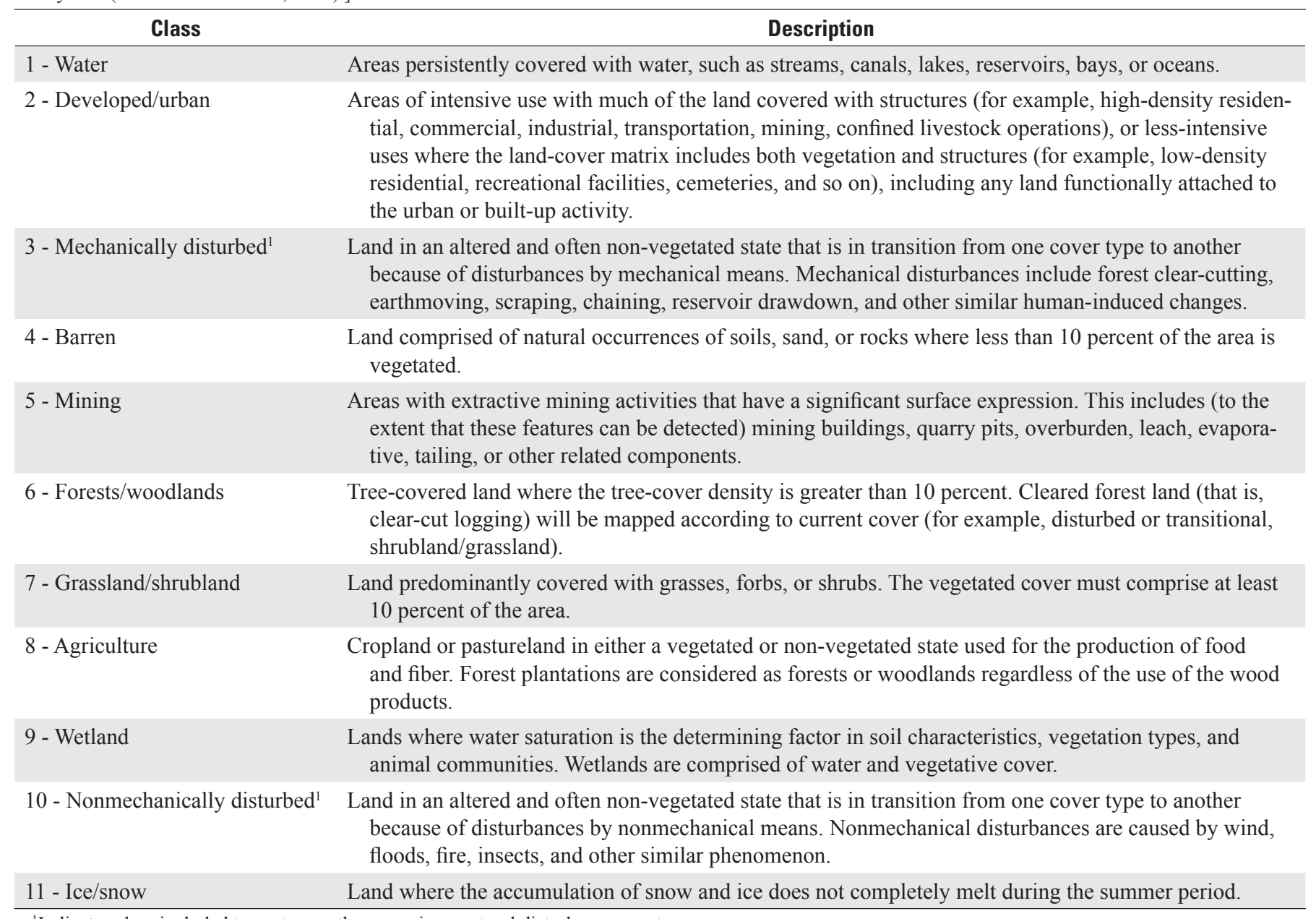

${ }^{1}$ Indicates class included to capture anthropogenic or natural disturbance events.

Table 4. Data sources and dates of ancillary data acquired to aid researchers in manually delineating land use and land cover from Landsat imagery.

[Aerial photography was acquired for each sample block to provide a high-resolution data source to aid in difficult interpretations. Availability of ancillary data varied, yet many datasets covered large spatial extents.]

\begin{tabular}{|c|c|c|}
\hline Data source & Data provider & Dates \\
\hline 7.5 Minute Topographic Maps & U.S. Geological Survey & Variable \\
\hline National Wetland Inventory (NWI) & U.S. Fish and Wildlife Service & Variable \\
\hline National High Altitude Program (NHAP) ${ }^{1}$ & U.S. Geological Survey & 1978-1980s \\
\hline National Aerial Photography Program (NAPP) ${ }^{1}$ & U.S. Geological Survey & $1987-1990 \mathrm{~s}$ \\
\hline Google Earth ${ }^{\mathrm{TM}}$ imagery ${ }^{1}$ & Google & 1990s-present \\
\hline
\end{tabular}

${ }^{1}$ Indicates aerial photography or satellite imagery. 


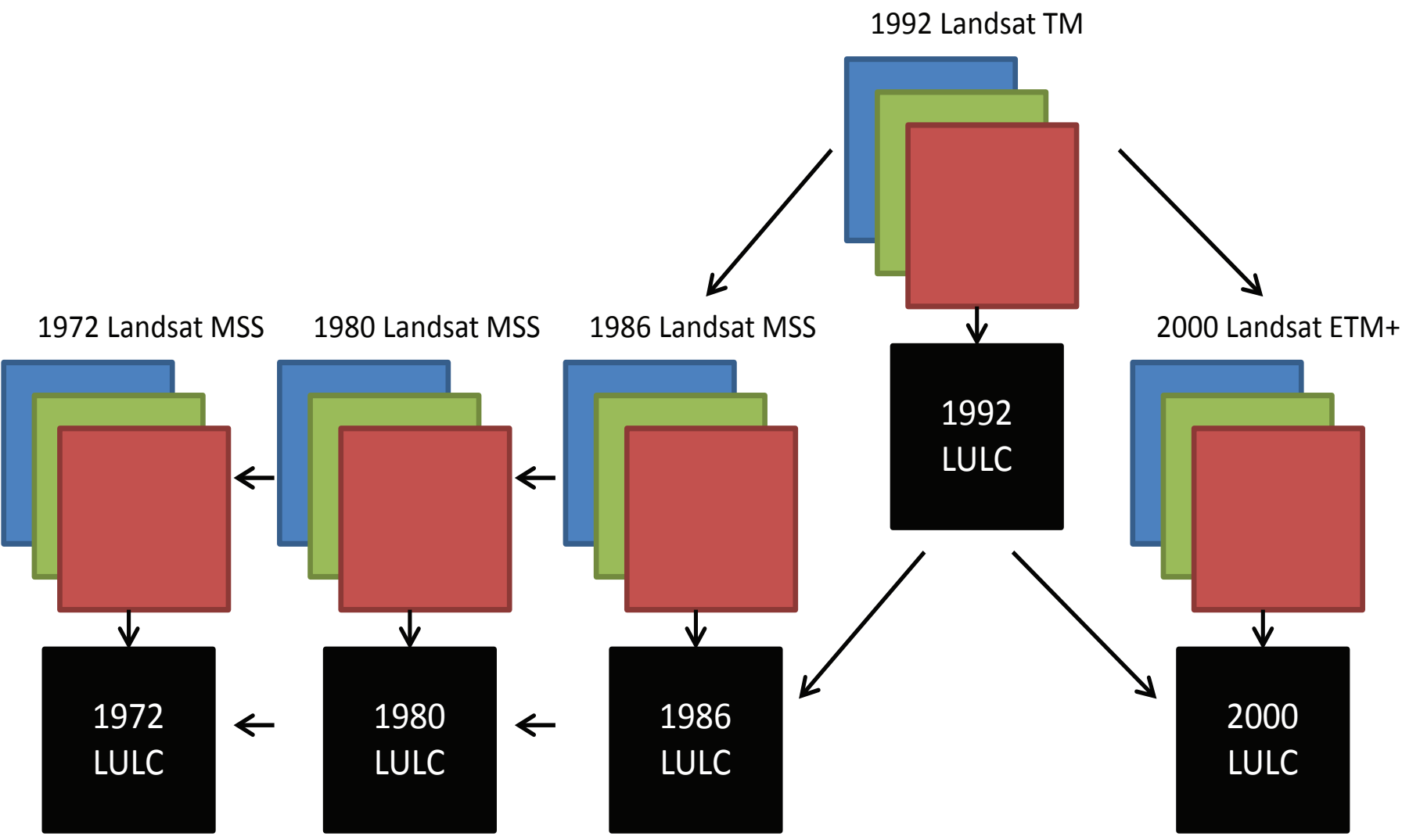

Figure 2. Flow diagram depicting block interpretation procedure used to develop Land Cover Trends Dataset. Manual interpretation process starts with development of 1992 baseline LULC. Resulting LULC map then was used to forward- and backward-classify areas that changed.

conducted by the national research team. During the block review, the national research team visually inspected each LULC date for each sample block by comparing interpreted maps to Landsat scenes and ancillary geospatial data. An examination of LULC adjacency also was conducted where blocks bordered one another. Review comments were compiled by the national research team and the researcher responsible for the interpretation was required to reconcile all errors following the block review and to document the corrections that were made.

\section{Data Download}

Five dates of LULC maps (1973, 1980, 1986, 1992, and 2000) are available for each of the 2,688 sample blocks distributed across the conterminous United States (fig. 3). The dataset includes a total of 13,440 images that are provided in a compressed file format by ecoregion. Each individual LULC map file is available in the ERDAS IMAGINE ${ }^{\mathrm{TM}}$ (.img) raster file format. The file name contains the ecoregion number, followed by the sample block number and the year of the Landsat used in the interpretation. The actual Landsat scenes are not available for download as part of this dataset.
The dataset is available for downloading at http://pubs.usgs.gov/ds/844/.

\section{References Cited}

Anderson, J.R., Hardy, E.E., Roach, J.T., and Witmer, D.E., 1976, A land use and land cover classification system for use with remote sensor data: U.S. Geological Survey Professional Paper 964, 28 p., http://pubs.er.usgs.gov/publication/pp964.

Fry, J., Xian, G., Jin, S., Dewitz, J., Homer, C., Yang, L., Barnes, C., Herold, N., and Wickham, J., 2011, Completion of the 2006 National Land Cover Database for the conterminous United States: Photogrammetric Engineering and Remote Sensing, v. 77, no. 9, p. 858-864.

Gillespie, A.J.R., 1999, Rationale for a national annual forest inventory program: Journal of Forestry, v. 97, no. 12, p. $16-20$.

Homer, C. C. Huang, L. Yang, B. Wylie and Coan, M., 2004, Development of a 2001 National Landcover Database for the United States. Photogrammetric Engineering and Remote Sensing, v. 70, no. 7, 829-840. 


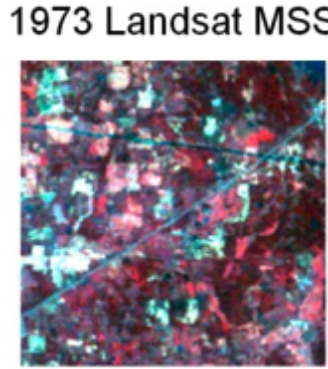

1973 LULC

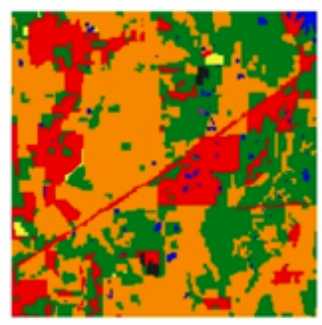

-Water -Developed
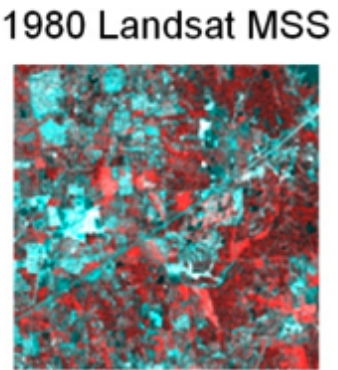

1980 LULC

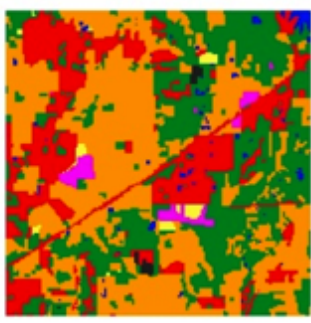

$\square$ Wetlands

-Mining
1986 Landsat MSS

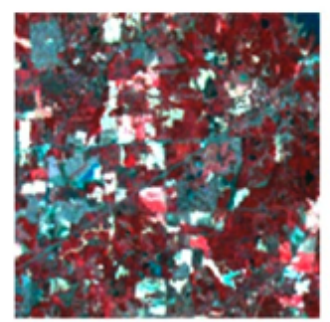

1986 LULC

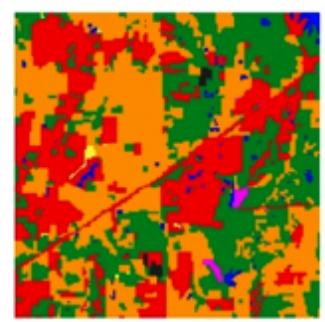

Barren

-Forest
1992 Landsat TM

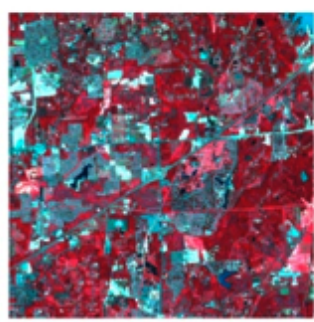

1992 LULC

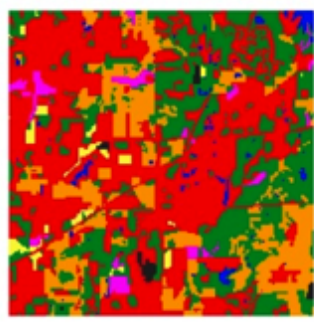

Grass/shrub

$\square$ Agriculture

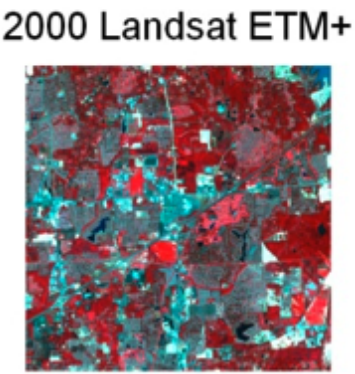

2000 LULC

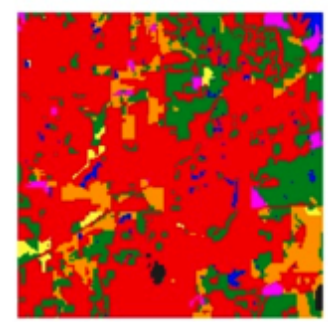

Mech.Dist.

Nonmech.Dist.

Figure 3. Example of five dates of LULC data available for each sample block. Data shown here are for sample 74 _0134 in the Mississippi Valley Loess Plains Ecoregion on the northeastern edge of Memphis, Tennessee. Landsat scenes are not available for download as part of this dataset.

Kish, L., 1987, Statistical design for research: New York, Wiley, 296 p.

Loveland, T.R., Sohl, T.L., Sayler, K., Gallant, A., Dwyer, J., Vogelmann, J.E., and Zylstra, G.J., 1999, Land cover Trends - Rates, causes, and consequences of late-twentieth century U.S. land cover change: Environmental Protection Agency, Research Plan EPA-IAG Project No. DW14938108-01-0, p. 1-52.

Loveland, T.R., Sohl, T.L., Stehman, S.V., Gallant, A.L., Sayler, K.L., and Napton, D.E., 2002, A strategy for estimating the rates of recent United States land-cover changes: Photogrammetric Engineering and Remote Sensing, v. 68, no. 10, p. 1091-1099.

Lunetta, R.S., Lyon, J.G., Guindon, B., and Elvidge, C.D., 1998, North American landscape characterization dataset development and data fusion issues: Photogrammetric Engineering and Remote Sensing, v. 64, no. 8, p. 821-829.

Multi-Resolution Land Characteristics Consortium, 2011, MRLC Landsat Scene Library: Web site, accessed July 20, 2012, at http://www.mrlc.gov/download_data.php.

Napton, D.E., Auch, R.F., Headley, R., and Taylor, J.L., 2010, Land changes and their driving forces in the Southeastern United States: Regional Environmental Change, v.10, no. 1, p.37-53.
Omernik, J.M., 1987, Ecoregions of the conterminous United States: Annals of the Association of American Geographers, v. 77 , no. 1, p. 118-125.

Raumann, C.G., and Soulard, C.E., 2007, Land-cover trends of the Sierra Nevada Ecoregion, 1973-2000: U.S. Geological Survey Scientific Investigations Report 2007-5011, 29 p, http://pubs.usgs.gov/sir/2007/5011/.

Sleeter, B.M., Sohl, T.L., Loveland, T.R., Auch, R.F., Acevedo, W., Drummond, M.A., Sayler, K.L., and Stehman, S.V., 2013, Land-cover change in the conterminous United States from 1973 to 2000: Global Environmental Change, v. 23, p. $733-748$.

Soulard, C.E., and Wilson, T.S., 2013, Recent land-use/landcover change in the Central California Valley: Journal of Land Use Science, doi:10.1080/1747423X.2013.841297.

Stehman, S.V., Sohl, T.L., and Loveland, T.R., 2003, Statistical sampling to characterize recent United States land-cover change: Remote Sensing of Environment, v. 86, p. 517-529.

U.S. Environmental Protection Agency, 1999, Level III ecoregions of the continental United States (revision of Omernik, 1987): U.S. Environmental Protection Agency National Health and Environmental Effects Research Laboratory, scale 1:7,500,000, Western Ecology Division, Corvallis, Oregon. 
U.S. Department of Agriculture, 2009a, 2007 Census of agriculture-United States summary and State data, Volume 1, Geographic Area Series, Part 51: U.S. Department of Agriculture, 639 p. plus appendixes.

U.S. Department of Agriculture, 2009b, Summary report-2007 National resources inventory: U.S. Department of Agriculture Natural Resources Conservation Service, and Iowa State University Center for Survey Statistics and Methodology, Ames, Iowa, 123 p.
Vogelmann, J.E., Howard, S.M., Yang, L., Larson, C.R., Wylie, B.K., and van Driel, N., 2001, Completion of the 1990s National Land Cover Data Set for the conterminous United States from Landsat Thematic Mapper data and ancillary data sources: Photogrammetric Engineering and Remote Sensing, v. 67, p. 650-662. 
Menlo Park and Tacoma Publishing Service Centers, California and Washington Manuscript approved for publication April 30, 2014

Edited by John Osias

Layout by Cory Hurd 
言

홍

变

흥

ฐ

홀

뭉

跑

ज्ञ

ปั

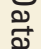

必

市.

$\stackrel{\infty}{\perp}$

http://dx.doi.org/10.3133/ds844

ISSN 2331-1258 (online) 